\title{
Purple Spot of Aloe (Aloe arborescens Mill.) Caused by Fusarium phyllophilum Nirenberg et O’Donnell (New Disease)
}

\author{
Kunihei KISHI*, Toshiko FuRUKAWA** and Takayuki AOKI***
}

\begin{abstract}
A new disease causing purple spots on leaves of candelabra aloe (Aloe arborescens Mill.) was found in Tahara-cho and Irako, Atsumi Peninsula, Aichi Pref. in October 1993. A species of Fusarium was isolated from lesions of many infected plants. This fungus was found to be pathogenic on $A$. arborescens by inoculation of wounded and intact leaves. The fungus was identified as Fusarium phyllophilum Nirenberg et O'Donnell on the basis of cultural and morphological characteristics. The disease was also observed at every location examined in Boso, Miura, Kii, Osumi, and Satsuma Peninsulas, where the climate is similar to that in Atsumi Peninsula. Four additional isolates from Jogashima Island were also identified as $F$. phyllophilum. This is the first report of the disease on $A$. arborescens in Japan.
\end{abstract}

(Received April 12, 1999 ; Accepted August 26, 1999)

Key words : Aloe arborescens, Fusarium phyllophilum, purple spot of aloe.

\section{INTRODUCTION}

More than 40 species of the genus Aloe have been cultured, mainly for ornamental purposes, but sometimes for medical use or as functional food in Japan ${ }^{7}$. Most species of Aloe originated in dry areas, mainly in tropical or subtropical Africa. They are cultured usually in glasshouses to be protected against the cold winters in Japan. Among them, candelabra aloe (Aloe arborescens Mill.) or Kidachi-aroe in Japanese, which is from South Africa, is relatively tolerant of lower temperatures. Cultivated from Hokkaido to Kyushu, it is the most popular species of Aloe in Japan. In most cases, the plants are potted and cultivated indoors or outdoors under house eaves. Most plants are healthy and without spots.

However, we found $A$. arborescens that most of the large plants in Tahara-cho on Atsumi Peninsula in Aichi, in a southern coastal region, in October 1993 had many purple spots of various sizes. These plants with multiple large stalks were growing semi-wildly in gardens or in fields and had been cultivated for many years near seashores (Plate I-1). In some cases spots enlarged so much that whole leaves withered. This phenomenon was considered to be a disease.

Fifteen diseases have been reported on Aloe barbadensis Mill. (=A. vera (L.) Webb. et Berth. non Mill.), $A$. variegata $\mathrm{L}$. and Aloe sp. in $\mathrm{USA}^{3}$. And three diseases have been reported in Japan; a rust of $A$. barbadensis, A. claviflora Burchell, $A$. dewettii Reynolds, $A$. karasbergensis Pillans, A. parvibracteata Schonl., and A. parvibracteata Schonl. var. zuluensis Reynolds caused by Uromyces aloes (Cooke) Magnus ${ }^{12)}$, Phytophthora rot of A. dichotoma Masson by Phytophthora nicotianae van Breda de Haan emend. G. Hall ${ }^{19)}$ and a foot rot of Aloe sp. by Fusarium dimerum Penzig var. dimerum ${ }^{11)}$. The present disease on $A$. arborescens was considered as a new one because it seemed different from those reported previously. A species of Fusarium was isolated from most material with purple spots collected in Atsumi Peninsula.

In this study, inoculation experiments with fungal isolates from host plants, identification of the isolates, and epidemiological studies were carried out to clarify the causal agents of the new disease and a possible reason for its incidence.

Kishi et al. ${ }^{6)}$ reported a preliminary study on this disease previously. They had tentatively identified the causal fungus as Fusarium proliferatum (Matsushima) Nirenberg ex Gerlach et Nirenberg var. minus Nirenberg, which was later elevated to the rank of species ${ }^{15}$.

\section{MATERIALS AND METHODS}

Fungal isolates One (AP1) of five pathogenic isolates we used was isolated from a small purple spot, ca. $2-3 \mathrm{~mm}$ in diam., on a surface-sterilized aloe leaf that

* Association for Advancement of Agricultural Science, Nishigahara, Kita-ku, Tokyo 114-0024, Japan

(財)農業技術 協会

** Tokyo Metropolitan College, Akishima-shi, Tokyo 196-8540, Japan＼cjkstart東京都立短期大学

*** National Institute of Agrobiological Resources, 2-1-2, Kannondai, Tsukuba 305-8602, Japan 
Table 1. Occurrence of the diseases on A. arborescens in various locations of Japan

\begin{tabular}{llllrr}
\hline \multicolumn{1}{c}{ City/Town } & Peninsula & Prefecture & Year & \multicolumn{2}{c}{ No. of plants } \\
\cline { 4 - 5 } & & & Examined & Diseased \\
\hline Tahara-cho Town & Atsumi & Aichi & 1994 & 15 & 15 \\
Irako, Atsumi-cho Town & Atsumi & Aichi & 1994 & 10 & 10 \\
Shirahama-cho Town & Boso & Chiba & 1996 & 12 & 12 \\
Chikura-cho Town & Boso & Chiba & 1996 & 15 & 8 \\
Miura City & Miura & Kanagawa & 1997 & 10 & 15 \\
Tanabe City & Kii & Wakayama & 1997 & 10 & 10 \\
Tarumizu City & Oosumi & Kagoshima & 1997 & 1997 & 8 \\
Ibusuki City & Satsuma & Kagoshima & 1997 & 1 \\
Nishigahara, Kita Ward & \multicolumn{2}{c}{ Tokyo } & 1997 & 100 & 89 \\
\hline
\end{tabular}

This disease was initially recognized at Tahara-cho Town, Atsumi Peninsula in 1993.

was collected on Tahara-cho, Atsumi Peninsula of Aichi Pref. in Oct. 1993. The other four isolates (Jo-I, II, III and VI) originated from conidia produced on old, large lesions on aloe leaves collected at Jogashima Island, Kanagawa Pref. in Oct. 1998.

Aloe plants for field observation and inoculation tests Field observations were made on $A$. arborescens growing outdoors at many sites on various peninsulas as described in Table 1 . These plants were old and large with numerous stalks as shown in Plate I-1. Potted $A$. arborescens outdoors in the town areas were also used for observation. They were relatively young, small stock. Other observations were made on nursery plants of $A$. arborescens in a plastic house at Tahara-cho in 1996. Plants of $A$. aculeata Pole-Evans, $A$. barbadensis, $A$. haemanthifolia Marloth et A. Berger, A. proteriensis Pole-Evans and $A$. variegata $\mathrm{L}$. sold in shops and $A$. africana Mill., A. ferox Mill., A. humilis (L.) Mill., A. dochotoma, and $A$. bainesii Dyer in a botanical garden in Ohito-cho, Shizuoka Pref. in 1999 also had the disease.

Inoculation tests Small, healthy plants of $A$. arborescens, $A$. vera and $A$. aculeata for inoculation tests were obtained from a local market. They were potted and cultured in a glasshouse for three separate series of inoculation tests. In the first series, either intact or wounded plants were inoculated in September 1994. Non-wound inoculations were for checking for natural infection of intact leaves. Wound inoculations were made to prove the pathogenicity of isolates and to compare susceptibility of, $A$. arborescens, $A$. vera, and $A$. aculeata. Inoculum was prepared by suspending conidia harvested from a $c a$. 2- week-old culture on PDA in sterilized water.

The second series of tests compared the pathogenicity of two types of inocula from the AP1 isolate in April 1994. Conidia were either harvested from a $c a$. 2-weekold culture that had been subcultured about one year on PDA or collected from a lesion of a diseased $A$. arborescens leaf after artificial inoculation. In this series Gibberella fujikuroi MAFF 305131, obtained from the MAFF Gene Bank System (Genetic Resources Center, National Institute of Agrobiological Resources, Minis- try of Agriculture, Forestry and Fisheries, Tsukuba, Ibaraki, Japan), was used as an additional inoculum. These experiments were replicated twice.

In the third series of tests, natural infectivity and pathogenicity of conidia produced naturally on Jogashima Island were examined after non-wound and wound inoculation, respectively, in October 1998. Naturally occurring conidia were harvested from four lesions, (sites Jo-I, II, III and VI) on diseased leaves and were suspended in the water to use as inocula. Four isolates (Jo-I, II, III, and VI), were obtained from the lesions and stored as representative strains.

For the non-wound inoculation, a suspension of conidia $\left(1 \times 10^{5}\right.$ conidia $\left./ \mathrm{ml}\right)$ was sprayed on intact plants. For the wound inoculation, a suspension of conidia $(1 \times$ $10^{5} \mathrm{conidia} / \mathrm{ml}$ ) was dropped onto three wounds on the upper surface of the leaves that were cut crosswise with a razor. The plants were covered with plastic bags after inoculation, then placed in a glasshouse or shady place outdoors for 48 hours. The bags were then removed, and the plants were kept under the same conditions. Sterilized water was used for a negative control.

The causal fungus was re-isolated from surfacesterilized tissues of typical lesions after both wound and non-wound inoculations.

Epidemiological observation Conidial formation in nature was examined twice using different methods. The first observation was made on naturally infected leaves bearing typical purple lesions collected at Tahara-cho, Irako, Miura City and Shirahama-cho in 1996 and 1997. The lesions were first observed with a magnifying glass. Surface of the lesions was then wiped with a wet cotton puff, and the puff was stamped onto the glass slides, which were examined under a microscope. The second observation was by naked eye on severely diseased whole plants on Jogashima Island, Kanagawa Pref. in 1998.

Examination of taxonomic characters of the causal fungus A single conidium was isolated from each stock strain from $A$. arborescens. The isolates were grown at $20^{\circ} \mathrm{C}$ on potato dextrose agar (PDA; Difco Lab., Detroit, MI) in $9 \mathrm{~cm}$ plastic petri dishes in the dark 
to determine growth rate, colony color, morphology and odor. Microscopic characters were examined in cultures growing on synthetic low nutrient agar (SNA; per liter dist. $\mathrm{H}_{2} \mathrm{O}: 1 \mathrm{~g} \mathrm{K \textrm {KH } _ { 2 }} \mathrm{PO}_{4}, 1 \mathrm{~g} \mathrm{KNO}$, $0.5 \mathrm{~g} \mathrm{MgSO}_{4} \cdot 7 \mathrm{H}_{2} \mathrm{O}$, $0.5 \mathrm{~g} \mathrm{KCl}, 0.2 \mathrm{~g}$ dextrose, $0.2 \mathrm{~g}$ sucrose, $0.6 \mathrm{ml} 1 \mathrm{~N} \mathrm{NaOH}$, $23 \mathrm{~g}$ agar) with two pieces of $c a .1 \times 2 \mathrm{~cm}$ sterile filter paper placed on the cooled surface ${ }^{13,14}$, for 14 days at $20^{\circ} \mathrm{C}$ in complete darkness or under continuous BLB (near-UV) light irradiation (Toshiba FL20S BLB$20 \mathrm{~W})^{2,14,18}$. The microdimensions of aseptate, aerial conidia and 1-, 3- and 5-septate sporodochial conidia were precisely measured for comparison with each other and with descriptions published previously ${ }^{2,5,13,15,17)}$. At least 30 conidia of each type were measured at random to calculate their arithmetic means and standard deviations (S.D.). The production of chlamydospores was examined microscopically on culture plates after 2- and 4 -wks of incubation. Colors cited are according to the Methuen Handbook of Colour ${ }^{8}$. Terminology describing fungal morphology mostly followed that of Nirenberg and O'Donnell ${ }^{15}$ ) to adjust our morphological findings to the recent rapid movement of Fusarium taxonomy ${ }^{1}$.

The strains examined were deposited in the MAFF Gene Bank System (Genetic Resources Center, National Institute of Agrobiological Resources, Ministry of Agriculture, Forestry and Fisheries, Tsukuba, Ibaraki, Japan) and in BBA (Institut für Pflanzenvirologie, Mikrobiologie und biologische Sicherheit, Biologische Bundesanstalt für Land- und Forstwirtschaft, BerlinDahlem, Germany).

Colony growth of the causal fungus at different temperatures Mycelial discs ( $5 \mathrm{~mm}$ in diam.) were cut from the margins of actively growing colonies. They were transferred to the center of $9-\mathrm{cm}$ PDA plate and incubated at seven temperatures ranging from $5^{\circ} \mathrm{C}$ to $35^{\circ} \mathrm{C}$ in the dark. Colony diameters of 7-day-old cultures were examined to find the optimal temperature for the growth of this fungus.

\section{RESULTS}

\section{Disease symptoms}

Infection was found on all parts of the plants except for roots. Lesions at an early stage were round, light purple spots (Plate I-2). They gradually enlarged and became sunken. Severely damaged leaves often bore more than 10 spots (Plate I-2, 3). Old lesions were more than $1 \mathrm{~cm}$ in diameter, deeply sunken, and reached the abaxial side (Plate I-6). The parts toward the tip from the large lesions were often killed. Conidial masses were not usually observed on the lesions, but when they were observed, they were on old lesions (Plate I-5, 6). The disease was not fatal even if the leaves of the stocks were severely damaged.

\section{Disease occurrence}

Numerous purple spots were found on $A$. arborescens cultivated outdoors at Tahara-cho on Atumi Peninsula in Aichi Pref. in 1993 (Plate I-1, 2). The fungus was isolated according to the method as described earlier. A species of Fusarium was detected at a high rate from a number of segments including purple spots on diseased leaves collected there. Fungi from other genera were isolated infrequently. Several single conidial isolates were established from the Fusarium species. Colony appearance of most isolates was similar to each other. The isolate AP1 was used for further experiments unless indicated otherwise. The same symptoms were observed on many of the $A$. arborescens plants examined at random in Tahara-cho and Irako on Atsumi Peninsula in Aichi Pref., Shirahama-cho and Chikura-cho on Boso Peninsula in Chiba Pref., Miura City on Miura Peninsula in Kanagawa Pref., Tanabe City in Wakayama Pref. and Tarumizu City and Ibusuki City in Kagoshima Pref. through 1994 to 1997 (Table 1). Of 12 potted plants growing under the eaves of private residences at the street-side or in the yard, only one diseased stock was found in Kita Ward, Tokyo in 1997. During these observations, rust caused by Uromyces aloes, Phytophthora rot by $P$. nicotianae and foot rot by Fusarium dimerum var. dimmerum were never found.

Purple spot was not observed on plants of $A$. aculeata, A. vera (=A. barbadensis), $A$. haemantifolia, A. pretoriensis and $A$. variegata in shops or on $A$. africana, $A$. ferox, $A$. humulis, $A$. dichotoma, and $A$. bainesii in a botanical garden in Ohito-cho, Shizuoka Pref. in 1999.

Table 2. Results of inoculation with AP1 of Fusarium phyllophilum on A. arborescens, A. vera and A. aculeata

\begin{tabular}{|c|c|c|c|c|c|c|}
\hline \multirow{3}{*}{ Treatment } & \multicolumn{6}{|c|}{ No. of plants } \\
\hline & \multicolumn{2}{|c|}{ A. arborescens } & \multicolumn{2}{|c|}{ A. vera } & \multicolumn{2}{|c|}{ A. aculeata } \\
\hline & Inoculated & Diseased & Inoculated & Diseased & Inoculated & Diseased \\
\hline Wound inoculation $^{\text {a) }}$ & 2 & 2 & 2 & 0 & 2 & 0 \\
\hline Control $^{\text {b) }}$ & 2 & 0 & 2 & 0 & 2 & 0 \\
\hline Non-wound inoculation ${ }^{c}$ & 2 & 2 & n.t. & - & n.t. & - \\
\hline Control $^{\text {d) }}$ & 2 & 0 & n.t. & - & n.t. & - \\
\hline
\end{tabular}

n.t., not tested.

a) Conidial suspension was dropped onto three wounds on the upper surface of the leaves, cut crosswise with a razor.

b) Water was dropped onto three wounds on the upper surface of the leaves, cut crosswise with a razor.

c) Conidial suspension was sprayed on intact plants.

d) Sterilized water was sprayed on intact plants. 


\section{Pathogenicity of the isolated fungus}

One month after inoculation of intact leaves of plants of $A$. arborescens with AP1, many purple spots like those seen on the naturally diseased plants of the $A$. arborescens were produced (Plate I-3). The same Fusarium species was again isolated from the lesions of the inoculated leaves.

In the case of the wound inoculation of three species of Aloe, i.e., A. arborescens, A. vera and A. aculeata, purple spots developed around the wound sites only on A. arborescens (Table 2, Plate I-4). In this case, the disease was initiated at all wounds and the lesions expanded faster than those after the non-wound inoculation.

In the second series of inoculations, three different inocula were used, i.e., conidia of AP1 produced on PDA or the aloe host or conidia of G. fujikuroi (MAFF 305131) produced on PDA. These inoculation tests were replicated twice. In both replications, all of the diseased plants developed typical lesions after inoculation with AP1 conidia formed on PDA or the host. Lesions formed at $56.9 \%$ of the sites inoculated with inoculum from PDA and $83.3 \%$ of those with inoculum from the host (Experiment 1). In Experiment 2, the values were $70.4 \%$ and $70.6 \%$, respectively, with inocula from PDA and from the host. On the contrary, lesions did not form on plants inoculated with $G$. fujikuroi and in the negative control (without fungal conidia) (Table 3).

In the third series of experiments, both of the intact plants became diseased after the non-wound inoculation with a conidial suspension from the Jo-II lesion (Table 4). Conidia from isolates Jo-I, II, III, VI and the original AP1 isolate were pathogenic to the host and infected all plants. The percentage of infection at inoculated wounds varied from 82 to $100 \%$ among the isolates. The average length of lesions caused by the isolates after one month ranged from 14.2 to $19.5 \mathrm{~mm}$ (Table 4). These lengths agreed well with those measured during the epidemio-

Table 3. Results of inoculation of wounded leaves of A. arborescens with conidia of Fusarium phyllophilum, produced on PDA or the host, or Gibberella fujikuroi

\begin{tabular}{|c|c|c|c|c|}
\hline \multirow[b]{2}{*}{ Inoculum } & \multicolumn{2}{|c|}{ Experiment- $1^{\text {a) }}$} & \multicolumn{2}{|c|}{ Experiment- $2^{\text {a) }}$} \\
\hline & $\begin{array}{l}\text { Percentage of } \\
\text { plants infected }^{\text {b) }}\end{array}$ & $\begin{array}{c}\text { Percentage of } \\
\text { inoculated points } \\
\text { infected }\end{array}$ & $\begin{array}{l}\text { Percentage of } \\
\text { plants infected }\end{array}$ & $\begin{array}{c}\text { Percentage of } \\
\text { inoculated points } \\
\text { infected }\end{array}$ \\
\hline \multicolumn{5}{|l|}{ F. phyllophilum } \\
\hline Conidia on $\mathrm{PDA}^{\mathrm{c})}$ & 100 & 56.9 & 100 & 70.4 \\
\hline Conidia on the host ${ }^{\mathrm{d}}$ & 100 & 83.3 & 100 & 70.6 \\
\hline G. fujikuro $i^{\mathrm{e})}$ & 0 & 0 & 0 & 0 \\
\hline Control & 0 & 0 & 0 & 0 \\
\hline
\end{tabular}

a) Conidial suspension or water (control) was dropped onto three wounds on the upper surface of the leaves, cut crosswise with a razor.

b) Four plants were inoculated.

c) Conidia from a ca. 2-week-old culture on PDA.

d) Conidia from a lesion on a $A$. arborescens leaf after artificial inoculation.

e) MAFF 305131.

Table 4. Comparison of the pathogenicity of five isolates of the pathogen on $A$. arborescens after wound inoculation

\begin{tabular}{|c|c|c|c|c|c|}
\hline Isolate & $\begin{array}{l}\text { No. of plants } \\
\text { inoculated }\end{array}$ & $\begin{array}{l}\text { No. of plants } \\
\text { infected }\end{array}$ & $\begin{array}{c}\text { No. of inoculated } \\
\text { sites }\end{array}$ & $\begin{array}{c}\text { Percentage of } \\
\text { infected sites }\end{array}$ & $\begin{array}{l}\text { Average length of } \\
\text { lesions }^{\text {a) }}(\mathrm{mm})\end{array}$ \\
\hline \multicolumn{6}{|c|}{ Non-wound inoculation ${ }^{\text {b) }}$} \\
\hline Jo-II ${ }^{\mathrm{d})}$ & 2 & 2 & - & - & - \\
\hline Controle) & 2 & 0 & - & - & - \\
\hline \multicolumn{6}{|c|}{ Wound inoculation ${ }^{\mathrm{c}}$} \\
\hline$A P 1^{f)}$ & 2 & 2 & 11 & 82 & 14.9 \\
\hline Jo-I ${ }^{\mathrm{d})}$ & 2 & 2 & 12 & 92 & 19.1 \\
\hline Jo-II ${ }^{\mathrm{d})}$ & 2 & 2 & 12 & 100 & 19.5 \\
\hline Jo-III ${ }^{d)}$ & 2 & 2 & 12 & 92 & 14.2 \\
\hline Jo-VId) & 2 & 2 & 12 & 83 & 14.5 \\
\hline Controle) $^{\mathrm{e}}$ & 2 & 0 & 12 & 0 & - \\
\hline
\end{tabular}

a) Length of lesions were measured after 1 month.

b) Conidial suspension or water (control) was sprayed on intact plants.

c) Conidial suspension was dropped onto three wounds on the upper surface of the leaves, cut crosswise with a razor.

d) Conidia harvested from natural lesions.

e) Sterilized water.

f) Conidia from a $c a$. 2-week-old culture on PDA. 
logical field observations. Some lesions caused by the wound inoculation had necrosis (Plate I-4).

\section{Epidemiological observation}

Epidemiological observation was made on two different types of materials : naturally occurred lesions collected at Shirahama-cho in 1996, and Tahara-cho, Irako, Miura City, in 1997 and lesions obtained after the artificial inoculations mentioned previously. Both types of materials contained various stages of symptom development, from small purple spots to large, deep lesions.

No fungal structures were observed with a magnifying glass on the surface of the lesions in any of 30 samples obtained from diseased leaves with several to many lesions on naturally diseased plants. Moreover, no conidia were found after the microscopic observation of the glass slides stamped with wet cotton by which lesions were wiped. On the lesions originating from inoculation of wounded leaves kept under high humidity, however, fungal structures such as aerial mycelia and conidia were occasionally observed (Plate I-5).

In October 1998, we thoroughly surveyed plants of $A$. arborescens on Jogashima Island to determine whether conidia developed on lesions in nature as they did after artificial inoculation. Six lesions with abundant sporulation were found on the diseased leaves of five huge $A$. arborescens (Plate I-6). This natural conidial production was observed only on large lesions under specific conditions as follows: All lesions formed in the middle of living leaves. Except for the lesion area, the other parts of the individual leaves were alive, even if the disease had progressed to where the fungus was sporulating on the lesions. These lesions were large, i.e., usually 10-20 $\mathrm{mm}$ in length and sometimes up to $30 \mathrm{~mm}$. Necrosis proceeded from the adaxial and aboxial surfaces of the leaf simultaneously. Conidia formed infrequently on the lesions; only six cases were found among the many lesions observed. On the small lesions of these leaves, no conidiation was found. Nor was conidiation observed on dead, dry, shrunken leaves. Individual conidia were collected from the six lesions, and four isolates (Jo-I, II, III and VI) were obtained. Natural infectivity and pathogenicity of the conidia were confirmed after non-wound

Table 5. Comparison of length and width of conidia produced by the strains of Fusarium phyllophilum

\begin{tabular}{|c|c|c|}
\hline Conidial type and isolate & Range (length $\times$ width) $(\mu \mathrm{m})$ & Mean \pm S.D. (length $\times$ width $)(\mu \mathrm{m})$ \\
\hline \multicolumn{3}{|l|}{ Aerial conidia (aseptate) } \\
\hline AP1 $\quad(=$ MAFF 237230) & $5-12 \times 2-4$ & $8.4 \pm 1.88 \times 2.8 \pm 0.46$ \\
\hline$(=$ MAFF 237752) & $4.5-14.5 \times 1.5-3.5$ & $7.8 \pm 2.23 \times 2.8 \pm 0.43$ \\
\hline Jo-II $\quad$ (=MAFF 237753) & $4.5-14 \times 2-3.5$ & $7.9 \pm 2.39 \times 2.8 \pm 0.34$ \\
\hline Jo-III (=MAFF 237754) & $3-15 \times 1.5-4$ & $8.3 \pm 2.91 \times 2.7 \pm 0.44$ \\
\hline Jo-VI (=MAFF 237755) & $4-12.5 \times 1.5-3.5$ & $8.6 \pm 2.12 \times 2.8 \pm 0.42$ \\
\hline Total range & $3-15 \times 1.5-4$ & \\
\hline Gerlach \& Nirenberg, 19825),a) & $3-20 \times 1.7-4.8$ & $8-10^{\mathrm{b})} \times 2.6^{-3.77^{\mathrm{b})}}$ \\
\hline Nirenberg \& O’Donnell, 1998 ${ }^{15)}$ & $5.6-16 \times 2.0-3.8$ & $9.4 \pm 2.4 \times 2.9 \pm 0.5$ \\
\hline \multicolumn{3}{|l|}{ Sporodochial conidia (1-septate) } \\
\hline AP1 $\quad(=$ MAFF 237230$)$ & $15.5-29 \times 2-3.5$ & $20.0 \pm 2.86 \times 2.8 \pm 0.20$ \\
\hline$(=\mathrm{MAFF} 237752)$ & $13.5-22 \times 2.5-3.5$ & $17.4 \pm 2.32 \times 2.8 \pm 0.23$ \\
\hline Jo-II （=MAFF 237753) & $15-23.5 \times 2.5-3.5$ & $18.9 \pm 2.42 \times 2.9 \pm 0.17$ \\
\hline Jo-III (=MAFF 237754) & $12.5-22.5 \times 2.5-3.5$ & $17.5 \pm 2.48 \times 2.9 \pm 0.24$ \\
\hline Jo-VI (=MAFF 237755) & $13-23 \times 2.5-3.5$ & $16.9 \pm 2.50 \times 3.0 \pm 0.21$ \\
\hline Total range & $12.5-29 \times 2-3.5$ & \\
\hline \multicolumn{3}{|l|}{ Sporodochial conidia (3-septate) } \\
\hline AP1 $\quad(=$ MAFF 237230$)$ & $20.5-41 \times 2.5-3.5$ & $32.0 \pm 6.13 \times 3.1 \pm 0.17$ \\
\hline Jo-I $\quad$ (=MAFF 237752) & $17.5-38 \times 2.5-4$ & $27.4 \pm 5.56 \times 3.1 \pm 0.29$ \\
\hline Jo-II （=MAFF 237753) & $18-41 \times 2.5-3.5$ & $30.5 \pm 6.21 \times 3.1 \pm 0.17$ \\
\hline Jo-III (=MAFF 237754) & $18.5-38.5 \times 2.5-3.5$ & $28.9 \pm 5.51 \times 3.1 \pm 0.18$ \\
\hline Jo-VI (=MAFF 237755) & $18-38.5 \times 2.8-4$ & $28.0 \pm 4.87 \times 3.2 \pm 0.21$ \\
\hline Total range & $17.5-41 \times 2.5-4$ & \\
\hline Gerlach \& Nirenberg, 19825),a) & $18-55 \times 2.0-4.0$ & $24-42^{\mathrm{b})} \times 2.5^{\left.-3.3^{\mathrm{b}}\right)}$ \\
\hline \multicolumn{3}{|l|}{ Sporodochial conidia (5-septate) } \\
\hline AP1 $\quad(=$ MAFF 237230) & $35.5-57 \times 3-4$ & $45.5 \pm 5.35 \times 3.3 \pm 0.19$ \\
\hline$(=$ MAFF 237752) & $31-50.5 \times 3-4$ & $38.9 \pm 4.72 \times 3.3 \pm 0.25$ \\
\hline Jo-II （=MAFF 237753) & $33.5-51 \times 3-4.5$ & $42.8 \pm 4.84 \times 3.2 \pm 0.27$ \\
\hline Jo-III （=MAFF 237754) & $36-68 \times 3-4$ & $47.9 \pm 9.15 \times 3.4 \pm 0.29$ \\
\hline Jo-VI (=MAFF 237755) & $31-46.5 \times 3-4$ & $38.8 \pm 4.37 \times 3.3 \pm 0.20$ \\
\hline Total range & $31-68 \times 3-4.5$ & \\
\hline Gerlach \& Nirenberg, $1982^{5, \text { a) }}$ & $36-71 \times 2.0-4.5$ & $50-57^{\mathrm{b})} \times 3.0-3.9^{\mathrm{b})}$ \\
\hline
\end{tabular}

a) Microdimensions as $F$. proliferatum var. minus ( $=F$. phyllophilum).

b) Range of mean values of the samples examined. 
and wound inoculation, respectively, as described previously (Table 4).

Morphological description and identification of the Fusarium isolates from $A$. arborescens

Based on cultural and morphological characteristics, as well as the pathogenicity of the isolates, the causal fungus was identified as Fusarium phyllophilum Nirenberg et O'Donnell. The strains are described as follows :

Fusarium phyllophilum Nirenberg et O’Donnell,
Mycologia 90 : 447. 1998.

三Fusarium proliferatum (Matsushima) Nirenberg ex Gerlach et Nirenberg var. minus Nirenberg, Mitt. Biol. Bundesanst. Land-Forstwirtsh. Berl.-Dahlem 169 : 43. 1976.

= Fusarium moniliforme Sheldon var. minus Wollenw.,

Z. Parasitenk. 3 : 397. 1931 (pro parte)

(Table 5, Fig. 1 and Plate II).

Radial colony growth on PDA $4.8^{-} 5.3 \mathrm{~mm}$ per day at $20^{\circ} \mathrm{C}$. Colony margins entire to undulate. Aerial mycelia

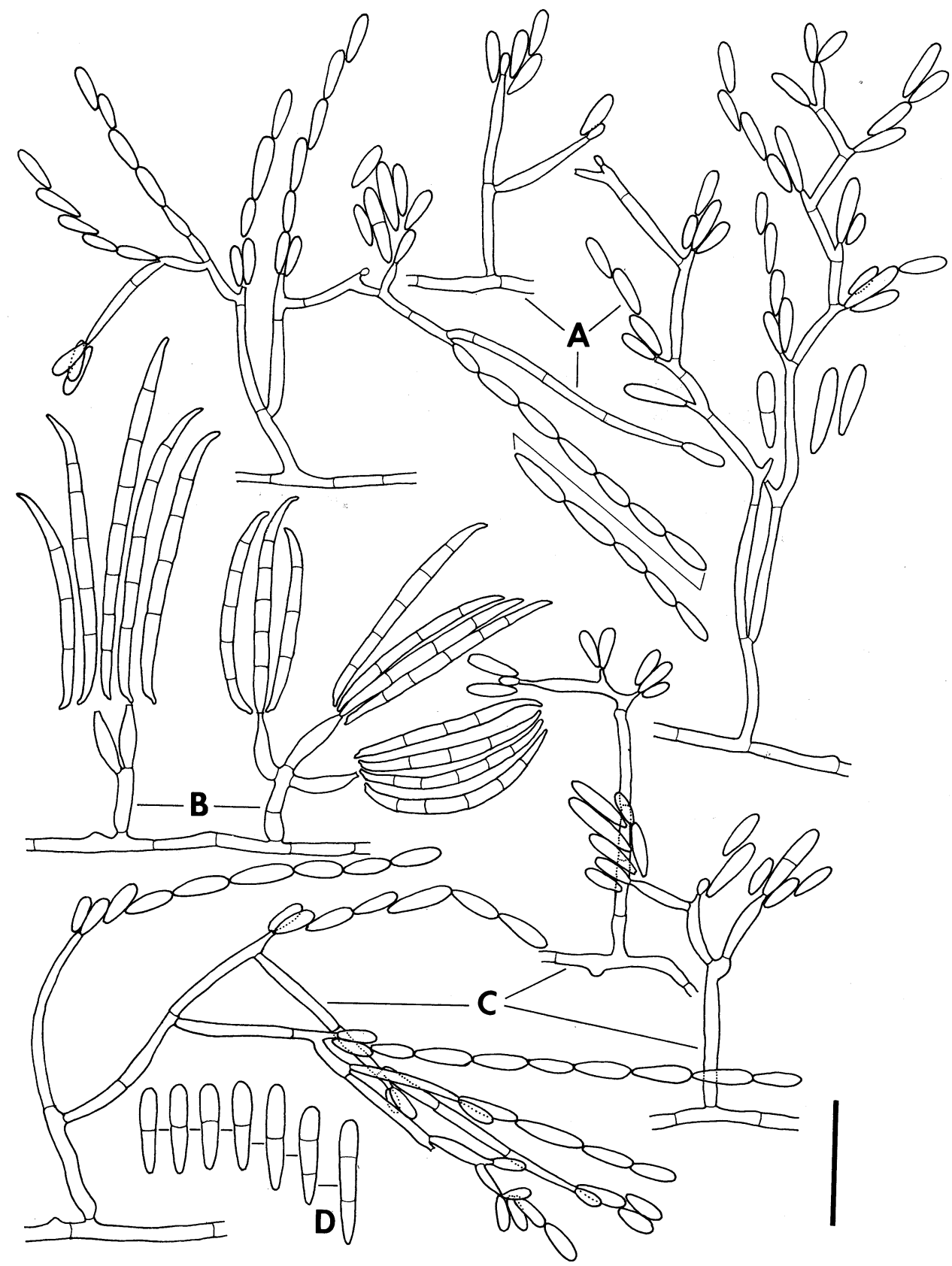

Fig. 1. Fusarium phyllophilum isolated from Aloe arborescens. A. Aerial conidiophores and conidia produced in pure culture on SNA under BLB light. Conidia were mostly aseptate and produced in linear and disordered false chains or in false heads from sympodially proliferating conidiogenous cells. B. Monophialidic sporodochial conidiophores and septate conidia produced in pure culture on SNA under BLB light. C. Aerial conidiophores and conidia produced in pure culture on SNA in complete darkness. D. Aerial conidia with one- to two-septa produced on SNA in complete darkness. Scale bar : $25 \mu \mathrm{m}$. 
at first white, becoming bluish gray, grayish blue, grayish violet, grayish magenta, violet blue to blue, abundantly developed, loosely to densely floccose. Reverse pigmentation white, grayish yellow, yellowish brown, olive brown, dulls violet to bluish gray. Hyphae 1.0-7.5 $\mu \mathrm{m}$ wide. Sclerotia absent. Odor somewhat sweet. Sporulation on SNA starting quickly on aerial mycelium or on conidiophores arising directly from the agar surface ; conidia formed mostly in false heads or in short linear or disordered false chains, but infrequently in rather long chains of up to 26 conidia, on the tips of sympodially proliferating conidiogenous cells (phialides), which give a powdery appearance to the cultures. Sporodochia with sparsely aggregated conidiophores, as an abbreviated form, produced on the agar-surface or submerged in the agar after 10 days only under BLB (near-UV) light irradiation. Aerial conidiophores at first unbranched, becoming loosely to densely branched, typically sympodial, some irregularly verticillate. Conidiogenous cells on the aerial conidiophores phialidic, some remaining monophialidic, mostly proliferating sympodially to become polyphialidic, up to $40 \mu \mathrm{m}$ long, $1-3 \mu \mathrm{m}$ wide ; sporodochial conidiogenous cells monophialidic, up to 25 $\mu \mathrm{m}$ long, $1.5-3.5 \mu \mathrm{m}$ wide, formed on loosely to densely branched short conidiophores. Aerial conidia (microconidia) elliptical to clavate with a truncate base, $0-1(-2)$ septate, occasionally tapering towards both ends; in complete darkness, 0 -septate : $3-15 \times 1.5-4 \mu \mathrm{m}$. Sporodochial conidia (macroconidia) produced only under BLB light irradiation, long fusiform, subfalcate to falcate, with an acuate apical cell and a distinct basal foot cells, (1-)3-5(-9)-septate; 1-septate : 12.5-29×2-3.5 $\mu \mathrm{m}, \quad 3$ septate : $17.5-41 \times 2.5-4 \mu \mathrm{m}$, 5 -septate : $31-68 \times 3-4.5 \mu \mathrm{m}$. Chlamydospores absent.

Strains examined: AP1 (=MAFF $237230=$ BBA 70335), isolated from A. arborescens, Tahara-cho, Atsumi Peninsula, Aichi Pref., Japan, K. Kishi, Oct. 1993 ; Jo-I (= MAFF 237752), Jo-II (= MAFF 237753), Jo-III (= MAFF 237754), Jo-VI (=MAFF 237755), isolated from $A$. arborescens, Jogashima Island, Miura Peninsula, Kanagawa Pref., Japan, K. Kishi, Oct. 1998.

Notes-Fusarium phyllophilum Nirenberg et O'Donnell has been considered as a variety of $F$. proliferatum (Matsushima) Nirenberg ex Gerlach et Nirenberg, i.e. F. proliferatum var. minus Nirenberg ${ }^{15}$. Microdimensions of isolates from A. arborescens examined, i.e., the size of aerial and sporodochial conidia on SNA (Table 5), are somewhat smaller in their mean values than those given by Nirenberg, and Gerlach and Nirenberg for $F$. proliferatum var. minus ${ }^{5,13}$. But the total range for each of the conidial types agreed quite well with them. Nirenberg and O'Donnell erected a new species, $F$. phyllophilum Nirenberg et O'Donnell based on the variety, $F$. proliferatum var. minus ${ }^{15}$. In the description of the new species, they provided only dimensions for aerial conidia, to which the aloe isolates also fit well, but not for sporodochial conidia. They stated "strains that are cultivated

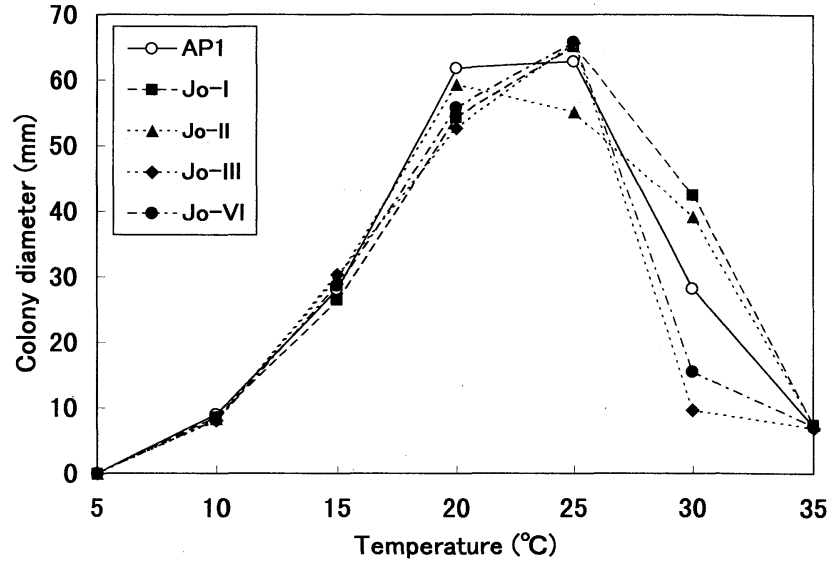

Fig. 2. Growth of mycelial colonies of Fusarium phyllophilum at different temperatures. Colony diameters of 7-day-old cultures in the darkness were measured.

for years produce a few thin, falcate conidia on the agar that are up to 5-septate". In the description for $F$. proliferatum var. minus, however, Gerlach and Nirenberg described that macroconidia (=sporodochial conidia) usually appeared only when irradiated with near-UV light ${ }^{5}$. In the original description of the variety, Nirenberg classified variations of strains into three types, related to their reactions in conidiogenesis to the near-UV light ${ }^{13}$. Reactions of the strains of these types to light conditions were described: Type I forming macroconidia in sporodochial masses under "black-light (near-UV light)", Type II forming no sporodochia and only a few scattered macroconidia even under "blacklight", and Type III forming typical macroconidia in pionnotes, and sometimes smaller macroconidia in minute sporodochia after $c a .2$ months. The most remarkable cultural characteristic of the isolates from $A$. arborescens was that production of sporodochia and sporodochial conidia were observed only under BLB light irradiation (Fig. 2B, Plate II-8, 9). The present isolates from $A$. arborescens apparently coincided with the Type I strains of her categories.

The unique response to near-UV light was also the key character for distinguishing the fungus from other known species and varieties with close morphological relationships ${ }^{5,13)}$. Fusarium proliferatum (Matsushima) Nirenberg ex Gerlach et Nirenberg (var. proliferatum), F. fujikuroi Nirenberg (teleomorph: Gibberella fujikuroi (Sawada) Wollenw. sensu str.) and $F$. subglutinans (Wollenw. \& Reinking) Nelson et al. (三F. sacchari (Butler) W. Gams var. subglutinans (Wollenw. \& Reinking) Nirenberg) produce sporodochial conidia without nearUV light irradiation. Production of sporodochial conidia only under near-UV light irradiation was also reported for $F$. sacchari (Butler) W. Gams ( $\equiv F$. sacchari var. sacchari $)^{5,13)}$ and $F$. globosum Rheeder et al. ${ }^{2,17}$. F. sacchari var. sacchari, as well as var. subglutinans, however, forms aerial conidia only in false heads but not in false chains, and $F$. globosum produces globose conidia 
in addition to clavate conidia. $F$. verticillioides (Saccardo) Nirenberg ( $=F$. moniliforme Sheldon s. str.) rarely produces sporodochial conidia and forms long chains of aerial conidia only from monophialides ${ }^{5,133}$. Therefore, the present fungus isolated from $A$. arborescens is obviously different from the species or the variety.

Other cultural characteristics of the aloe isolates, such as colony morphology and color on PDA, their formation of false heads and chains of aerial conidia (Fig. 2-A, C, Plate II-1, 2), aerial conidiophore morphology (Fig. 2-A, C, Plate II, 4-6), mode of conidiogenesis, and the absence of chlamydospores agreed well with the descriptions for the species/variety.

On the purple spots of diseased leaves of $A$. arborescens in the present study, sporodochium-like mycelial tufts, $c a .50-200 \mu \mathrm{m}$ in diam., were covered by numerous conidia. The morphology of these conidia, mostly elliptical to clavate with a truncate base, $0(-1)$-septate, $5-11 \times$ 2-3 $\mu \mathrm{m}$, corresponded to that of the aerial conidia produced in pure culture.

Fusarium phyllophilum ( $\equiv F$. proliferatum var. minus) has been reported to colonize and be pathogenic to thick leaved plants, such as the Dracaenaceae (Dracaena and Sansevieria) and Asphodelaceae (Gasteria), on which they may cause severe leaf lesions ${ }^{5,13,15)}$, as found in the present study.

According to the collective morphological and ecological features, such as production of sporodochial conidia only under the BLB light irradiation, aerial conidia formed in false heads and in linear, disordered false chains from sympodially proliferating conidiophores, and the absence of globose conidia and chlamydospores, the examined Aloe isolates were identified as F. phyllophilum.

\section{Optimal growth temperature of the Fusarium isolates from $A$. arborescens}

As shown by the colony diameters of 7-day-old cultures of the strains on PDA in 9-cm petri dishes at temperatures ranging from $5^{\circ} \mathrm{C}$ to $35^{\circ} \mathrm{C}$ (Fig. 2), these strains grew well between $15^{\circ} \mathrm{C}$ and $30^{\circ} \mathrm{C}$. The optimal temperature was $25^{\circ} \mathrm{C}$, except for strain Jo-II from Jogashima Island.

\section{DISCUSSION}

A new disease caused by Fusarium phyllophilum was found on Aloe arborescens, (Kidachi-aroe) and named purple spot (Shihan-byo) of aloe. Although rust, Phytophthora rot and foot rot have already been reported on eight species of Aloe in Japan ${ }^{11,12,19)}$, no disease has been reported on $A$. arborescens. This is, therefore, the first disease report on $A$. arborescens in Japan. Crown and root rot of Aloe caused by Fusarium oxysporum, which has been reported from United States, is quite different from purple spot in symptoms and pathogen ${ }^{3}$.

The same symptom was commonly found on $A$. arborescens cultured outdoors in the warm coastal regions of Japan, such as the Boso, Miura, Atsumi, Kii, Satsuma and Osumi Peninsulas. On Jogashima Island in Miura Peninsula, Kanagawa Pref., four strains of Fusarium were subsequently isolated from different plants of $A$. arborescens. They were also identified as $F$. phyllophilum.

The disease could not be found on any other Aloe species, including $10 \mathrm{spp}$. in botanical gardens and shops surveyed for the present study. Nor did artificial inoculation with the pathogen of two other Aloe species did not result in disease. On the other hand, Fusarium phyllophilum ( $\equiv F$. proliferatum var. minus) has been reported to be pathogenic to Dracaena in Italy and Sansevieria and Gasteria in Germany, on which they caused severe leaf lesions ${ }^{5,13,15)}$. Further studies on the host ranges of different isolates of $F$. phyllophilum, as well as on the host specificity of the fungal species, are necessary.

Only purple spot was frequently observed when 89 stocks of $A$. arborescens cultured outdoors from Kanto to Kyushu districts were surveyed for the occurrence of the four diseases recorded on Aloe spp. in Japan. This indicates that purple spot is a common, wide spread disease of $A$. arborescens in Japan. The disease will probably become important if the culture of $A$. arborescens increases.

Based on the results of epidemiological observations, incidence factors of the disease in some typical cases were considered as follows. In Jogashima Island in October 1998, only six fully sporulating lesions were found on five large diseased aloe plants. However, a number of diseased plants had numerous non-sporulating purple spots. The sporulating lesions produced abundant conidia, which had a high infectivity on wounded and intact leaves of $A$. arborescens.

In Atsumi-cho, Aich Pref. in October 1996, severe damage was found in all of the more than 200 nursery plants grown in a closed plastic house. Because a large diseased plant of $A$. arborescens was growing in front of the plastic house, the disease indoors may have been caused by irrigation water or sprinkling equipment contaminated with the pathogen from the diseased plant.

In Kita Ward, Tokyo in 1997, only one plant of 12 grown outdoors for 5 to 10 years at street-side or in the yard was diseased. This plant may already have been infected before it was transplanted. The disease probably did not spread to the other plants because they were cultured separately.

Almost all of the large plants cultivated outdoors were severely diseased, and they usually had many purple spots on leaves, stems and flower stalks as shown in Plate I-2. The disease could therefore have been in the typical epidemic stage as proposed by E. Gaümann ${ }^{4}$. But we found no evidence of sporulation on the numerous purple spots and dead leaves we examined from 1994 to 1997. In October 1998, however, lesions with numerous conidia on the both surfaces of the leaves were found at Jogashima Island in Miura Peninsula as described earlier. This fact and the high infectivity of conidia of the 
causal fungus may together represent the "high numeral fertility" for an epidemic as a result of sporulating lesions.

Conidia produced naturally on lesions caused the outbreak of this disease in one area by the probable transmission of conidia to healthy leaves. Wind or water from rain, dew, sprinkling or splashing water could probably disseminate the conidia ${ }^{9,10}$.

O'Donnell et al. showed that Fusarium phyllophilum belonged to the African clade of the Gibberella fujikuroi species complex during their analyses based on nucleotide base sequences of the $28 \mathrm{~S}$ rDNA, mitochondrial small subunit (mtSSU) rDNA, and $\beta$-tubulin ${ }^{16)}$. On the other hands, F. fujikuroi (teleomorph: G. fujikuroi s. str.) and $F$. proliferatum were found to belong to the Asian clade together with several other species. Because the origin of the species of Aloe is Africa and its surrounding area, the combination of the host and the pathogen in the present disease coincided well.

Aoki and Nirenberg ${ }^{2)}$ discussed the reactions of Fusarium species to light conditions with reference to their habitats and suggested that the induction of conidiogenesis by near-UV light could be an important feature of the species inhabiting areas under intense sunshine. In the present study, $F$. phyllophilum and purple spot were isolated and detected from $A$. arborescens cultured outdoors in the warmer, sunnier regions of Japan. Isolates of $F$. phyllophilum examined in the present study produced sporodochial conidia only under the BLB light. These findings also corresponded well with the discussion by Aoki and Nirenberg ${ }^{2}$.

This collective information suggests that purple spot of aloe, as well as the pathogen $F$. phyllophilum, may have been introduced from foreign countries together with the host plants, which were probably symptomless, during transportation.

The authors would like to express their cordial thanks to Dr. H. I. Nirenberg, Institut für Pflanzenvirologie, Mikrobiologie und biologische Sicherheit, Biologische Bundesanstalt für Land- und Forstwirtschaft, Berlin-Dahlem, Germany, for her kind confirmation of their identification of the original isolate, AP1 (=MAFF $237230=\mathrm{BBA} 70335)$ and helpful comments concerning the species.

\section{Literature cited}

1. Aoki, T. (1998). Current situation of the taxonomy of the genus Fusarium. Soil Microorganisms $52: 73-83$ (in Japanese).

2. Aoki, T. and Nirenberg, H. (1999). Fusarium globosum from subtropical Japan and the effect of different light conditions on its conidiogenesis. Mycoscience $40: 1-9$.

3. Farr, D.F., Bills, F.G., Chamuris, P.G. and Rossman, Y. A. (1989). In Fungi on Plants and Plant Products in the United States, APS Press, St. Paul, p. 273.

4. Gaümann, E. (1950). In Principles of Plant Infection, Crosby Lockwood \& Son, London, pp. 154-155.

5. Gerlach, W. and Nirenberg, H. (1982). The genus
Fusarium-a pictorial atlas. Mitt. Biol. Bundesanst. Land-Forstwirtsch. Berl.-Dahlem 209 : 1-406.

6. Kishi, K., Aoki, T., Furukawa, T. and Kobayashi, T. (1997). New disease of aloe, Aloe spp. caused by Fusarium proliferatum (Matsushima) Nirenberg var. minus Nirenberg. Ann. Phytopathol. Soc. Jpn. 63: 202 (Abstr. in Japanese).

7. Kishi, M. and Matsui, K. (1994). In Encyclopedia of Horticultural Plants (Engei Shokubutsu Daijiten), Vol. 1 (Tsukamoto, Y. ed.), Shogakukan, Tokyo, pp. 173-179 (in Japanese).

8. Kornerup, A. and Wanscher, J.H. (1978). Methuen Handbook of Colour, 3rd ed., Eyre Methuen, London.

9. Lacey, J. (1981). The aerobiology of conidial fungi. In Biology of Conidial Fungi, Vol. 1 (Cole, G.T. and Kendrick, B. eds.), Academic Press, New York, pp. 373-416.

10. Malloch, D. and Blackwell, M. (1992). Dispersal of fungal diaspores. In The Fungal Community, Its Organization and Role in the Ecosystem, 2nd ed. (Carroll, G.C. and Wicklow, D.T. eds.), Marcel Dekker, New York, pp. 147-171.

11. Motohashi, K., Aoki, T. and Kobayashi, T. (1998). Foot rot of aloe caused by Fusarium dimerum. Ann. Phytopathol. Soc. Jpn. 64 : 435 (Abstr. in Japanese).

12. Nakamura, S., Sato, S. and Katsuya, K. (1976). Notes on Uromyces aloes (Cooke) P. Magnus on the cultivated species of Aloe in Japan. Trans. Mycol. Soc. Japan 17 : 342-344 (in Japanese).

13. Nirenberg, H.I. (1976). Untersuchungen über die morphologische und biologische Differenzierung in der Fusarium-Sektion Liseola. Mitt. Biol. Bundesanst. LandForstwirtsch. Berl.-Dahlem 169 : 1-117.

14. Nirenberg, H.I. (1990). Recent advances in the taxonomy of Fusarium. Stud. Mycol. 32 : 91-101.

15. Nirenberg, H.I. and O'Donnell, K. (1998). New Fusarium species and combinations within the Gibberella fujikuroi species complex. Mycologia 90 : 431-458.

16. O'Donnell, K., Cigelnik, E. and Nirenberg, H.I. (1998). Molecular systematics and phylogeography of the Gibberella fujikuroi complex. Mycologia 90 : 465-493.

17. Rheeder, J.P., Marasas, W.F.O. and Nelson, P.E. (1996). Fusarium globosum, a new species from corn in southern Africa. Mycologia 88 : 509-513.

18. Seemüller, E. (1968). Untersuchungen über die morphologische und biologische Differenzierung in der Fusarium-Sektion Sporotrichiella. Mitt. Biol. Bundesanst. Land-Forstwirtsch. Berl.-Dahlem 127 : 1-93.

19. Uematsu, S., Suzui,T., Sekiyama, K. and Nakamura, Y. (1995). Phytophthora rots of Aloe dichotoma and Anemone coronaria caused by Phytophthora nicotianae. Ann. Phytopathol. Soc. Jpn. 61 : 219 (Abstr. in Japanese).

\section{和 文 摘 要}

\section{岸 國平・古川聡子・青木孝之: Fusarium phyllophilum によ} るアロエ紫斑病（新称）

1993 年 10 月愛知県渥美郡田原町 (渥美半島)において, 野外 で栽培中のキダチアロエ (Aloe arborescens Mill.) に，紫色の 斑点を多数生ずる病害の発生を認めた。病斑部からはFusarium 属菌が容易に分離され, これらはキダチアロエに対し, 有 傷および無傷接種でいずれも強い病原性を示した。培養的性質 
ならびに形態から本菌を Fusarium phyllophilum Nirenberg et O’Donnell と同定した。1994 年から 1997 年までの調査の結果, 渥美半島のほか, 房総, 三浦, 紀伊, 大隅, 薩摩等の各半島にお いても本病は野外で栽培中のキダチアロエに広く発生が認めら れた。1998 年 10 月, 三浦半島城ヶ島において多量に分生子を形
成する病斑を見いだし，それらから菌を分離して新たに 4 菌株 を得たが,これらもすべて F. phyllophilum と同定された。以上 より本病を新病害と認め, アロエ紫斑病 (purple spot of Aloe) と呼称することを提案する.

\section{Explanation of plates}

Plate I Symptoms and/or signs of purple spot of aloe. 1. A large aloe (A. arborescens) plant with many diseased leaves. 2. Symptom of purple spots on naturally infected leaves. 3. Purple spots formed after inoculation of intact leaves. 4 . Necrotic lesions formed after inoculation with Jo-II of wounded leaf. 5. Sporulation on a lesion after inoculation of wounded leaf. 6 . Sporulation on a lesion after natural infection.

Plate II Conidiomata of Fusarium phyllophilum isolated from Aloe arborescens (1, 3-6, 8, 9 on SNA under BLB irradiation; 2, 7 on SNA in complete darkness). 1. Aerial conidiophores and conidia produced in long chains. 2. Aerial conidiophores and conidia produced in false chains or in a false head. 3. Aerial conidiophores and conidia produced in false heads from sympodially proliferating conidiogenous cells. 4. Irregularly branched aerial conidiophore with sympodially proliferating conidiogenous cells. 5. Aerial conidiophore showing sympodially proliferating conidiogenous loci. 6. Branched aerial conidiophore showing sympodially proliferating conidiogenous loci. 7. Aerial aseptate conidia. 8 and 9. Sporodochial conidiophores and septate conidia. Scale bars ; 1-3, 8 and $9: 50 \mu \mathrm{m} ; 4-7: 20$ $\mu \mathrm{m}$. 


\section{Plate I}
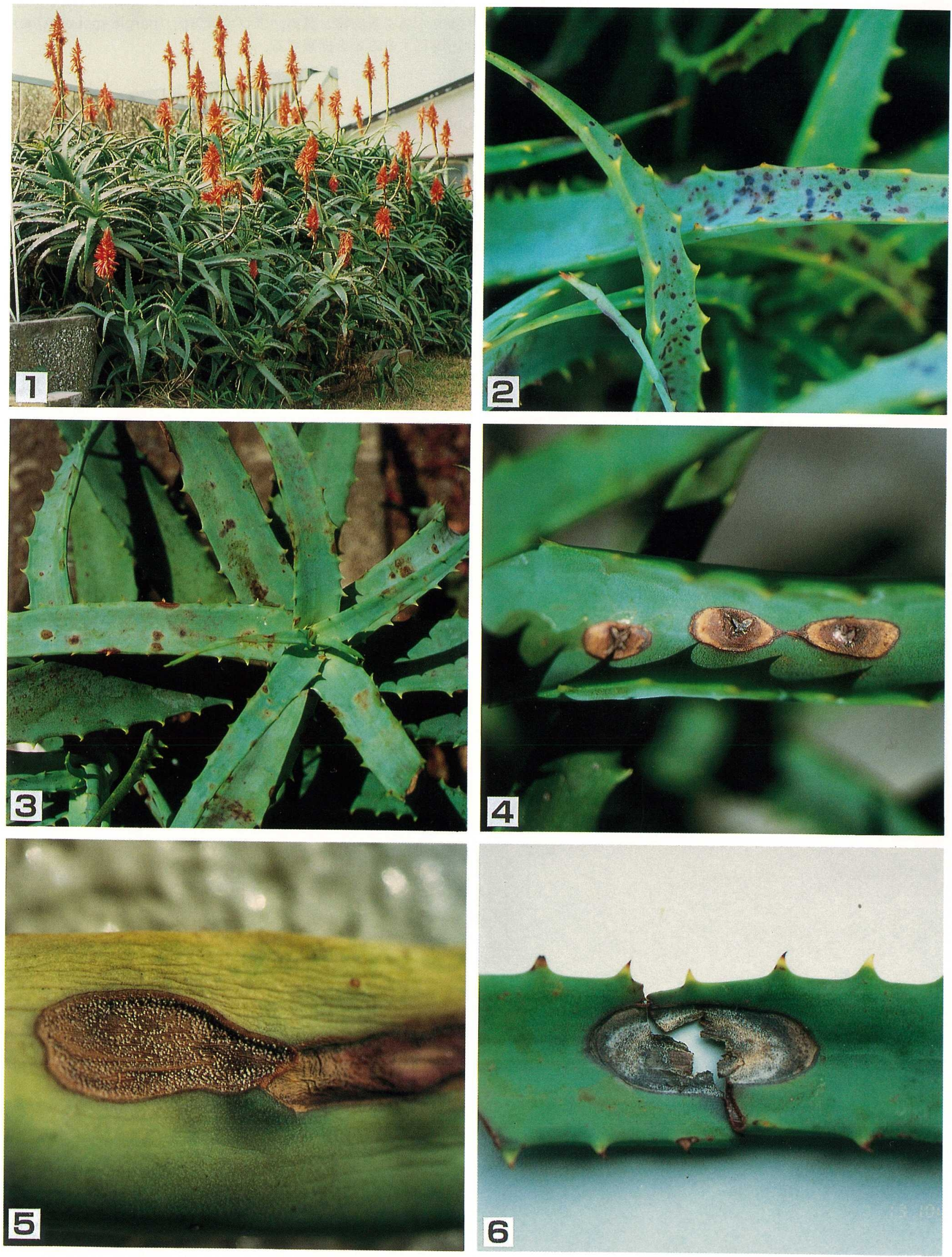


\section{Plate II}
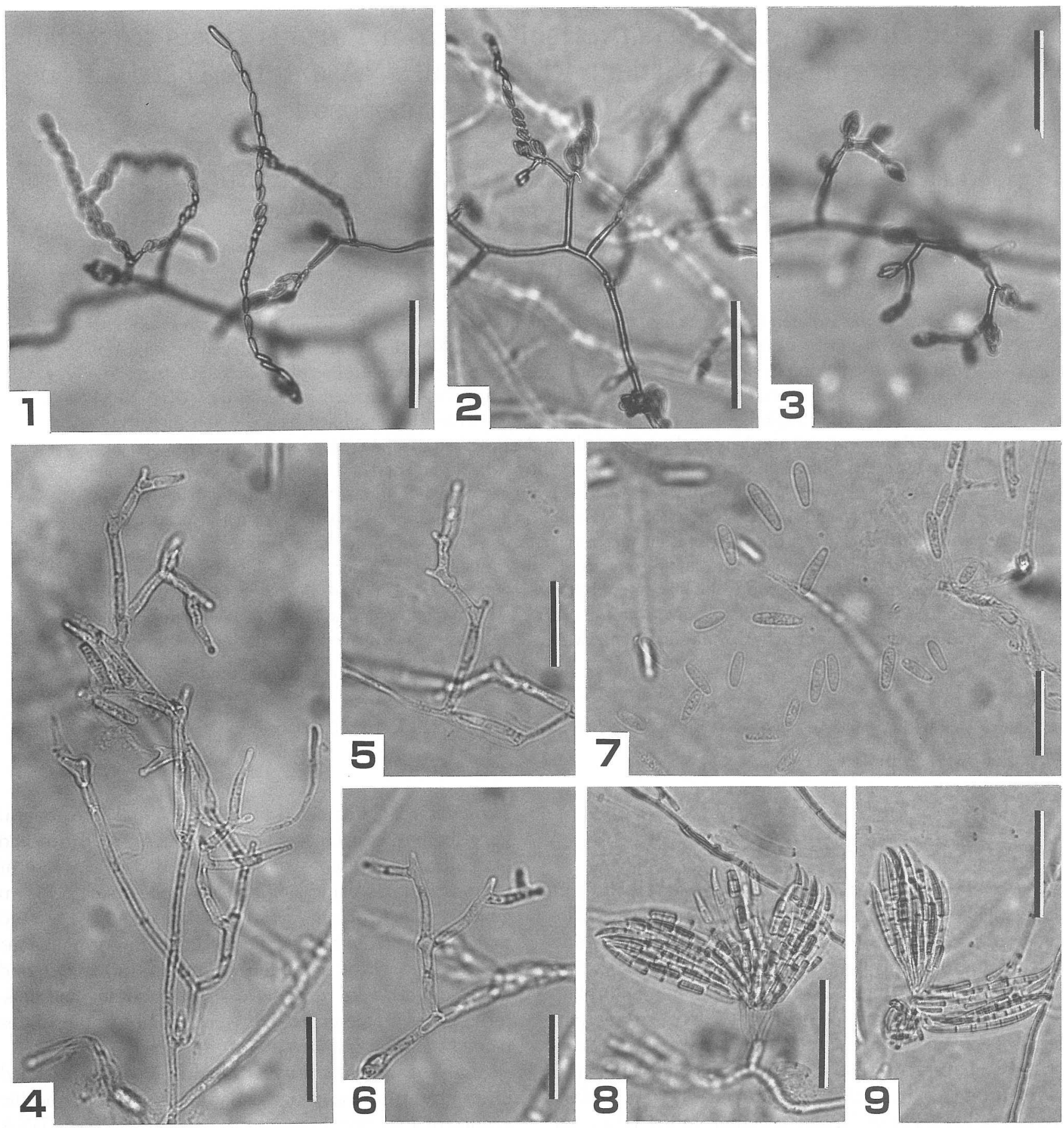